\title{
Plants of the Araceae family for malaria and related diseases: a review
}

FRAUSIN, G.1; LIMA, R.B.S.1; HIDALGO, A.F.1; MING, L.C. ${ }^{2}$; POHLIT, A.M.." ${ }^{3 *}$

Universidade Federal do Amazonas (UFAM), Av. Gal. Rodrigo Octávio, 6200, Coroado I, CEP 69077-000, Manaus-Brazil. 2Universidade Estadual de São Paulo (UNESP), R. José Barbosa de Barros, 1780, Campus de Botucatu, CEP 18610-307, Botucatu-Brazil. ${ }^{3}$ Instituto Nacional de Pesquisas da Amazonia (INPA), Av. André Araújo, 2936, Petrópolis, CEP 69080-971, Manaus-Brazil. *Autor para correspondencia: ampohlit@inpa.gov.br

RESUMO: Plantas da família Araceae para a malária e doenças relacionadas: uma revisão. No presente trabalho realizamos uma revisão das espécies da família Araceae usadas para tratar malária e seus sintomas. O objetivo foi revelar o grande número de espécies da família usadas no mundo, assim como seu potencial como fontes de produtos naturais antimaláricos. Foram consultadas as plataformas de busca SciFinder Scholar, Scielo, PubMed, ScienceDirect e Google books. Encontramos quarenta e três registros de 36 espécies e 23 generos de Aráceas usadas para tratar malária e seus sintomas. Os generos neotropicais Philodendron Schott e Anthurium Schott foram os melhor representados, úteis para o tratamento da malária, febres, problemas hepáticos e dores de cabeça. Folhas e tubérculos foram as partes mais utilizadas, enquanto a decocção foi o método de preparo mais comum. Os extratos de espécies de Araceae inibem o crescimento in vitro do parasito da malária humana, Plasmodium falciparum Welch, e concentrações inibitórias medianas $\left(\mathrm{Cl}_{50}\right)$ significativas foram relatadas para extratos de guaimbê-sulcado (Rhaphidophora decursiva (Roxb.) Schott), aninga (Montrichardia linifera (Arruda) Schott), Culcasia lancifolia N.E. Br. e anchomanes do mato (Anchomanes difformis (Blume) Engl.), demonstrando o potencial antimalárico e citotóxico de extratos e subfrações. No único relato sobre os componentes antimaláricos dessa família, a neolignana polisiforina e o benzoperóxido rafidecurperoxina apresentaram forte inibição das cepas D6 e W2 de Plasmodium falciparum in vitro $\left(\mathrm{Cl}_{50}=368-540 \mathrm{ng} / \mathrm{mL}\right)$. Nenhum estudo sobre a atividade antimalárica in vivo em modelo animal foi realizado com espécies da família Araceae. Mais trabalhos biomonitorados pela composição química sobre a atividade antimalárica in vitro, assim como estudos in vivo, são necessários para aprofundar os conhecimentos sobre potencial antimalárico da familia.

Palavras-chave: Anthurium, Philodendron, Rhaphidophora decursiva, Plasmodium falciparum, planta antimalárica.

ABSTRACT: In the current work we performed a review of the Araceae family species traditionally used to treat malaria and its symptoms. The aim is to reveal the large number of antimalarial Araceae species used worldwide and their great unexplored potential as sources of antimalarial natural products. The SciFinder Scholar, Scielo, PubMed, ScienceDirect and Google books search engines were consulted. Forty-three records of 36 species and 23 genera of Araceae used for malaria and symptoms treatment were found. The neotropical genera Philodendron Schott and Anthurium Schott were the best represented for the use in the treatment of malaria, fevers, liver problems and headaches. Leaves and tubers were the most used parts and decoction was the most common preparation method. The extracts of Araceae species inhibit the in vitro growth of the human malaria parasite, the Plasmodium falciparum Welch, and significant median inhibitory concentrations ( $\mathrm{IC}_{50}$ ) for extracts of guaimbê-sulcado (Rhaphidophora decursiva (Roxb.) Schott), aninga (Montrichardia linifera (Arruda) Schott), Culcasia lancifolia N.E. Br. and forest anchomanes (Anchomanes difformis (Blume) Engl.) have been reported demonstrating the antimalarial and cytotoxicity potential of the extracts and sub-fractions. In the only report about the antimalarial components of this family, the neolignan polysyphorin and the benzoperoxide rhaphidecurperoxin presented strong in vitro inhibition of the D6 and W2 strains of Plasmodium falciparum $\left(\mathrm{IC}_{50}=368-540 \mathrm{ng} / \mathrm{mL}\right)$. No live study about antimalarial activity in animal models 
has been conducted on a species of Araceae. More bioguided chemical composition studies about the in vitro and also thein vivo antimalarial activity of the Araceae are needed in order to enhance the knowledge about the antimalarial potential of this family.

Keywords:Anthurium, Philodendron, Rhaphidophora decursiva, Plasmodium falciparum, antimalarial plant.

\section{INTRODUCTION}

Malaria is caused by protozoans of the genus Plasmodium that are transmitted to humans by the bite of infected, female Anopheles mosquitos. Malaria symptoms include fevers, headaches, vomiting and chills that appear 10-15 days after infection (WHO, 2014). Despite advances in its control and prevention in the past decade, malaria continues to be one of the world's major transmissible diseases. It is responsible for high mortality in tropical and sub-tropical regions of the planet (Muñoz et al., 2000; Adebayo \& Krettli, 2011; Tsabang et al., 2011). Several factors contribute to the unacceptably high malaria morbidity and mortality rates. The major human malaria parasites Plasmodium falciparum Welch and P. vivax Grassi \& Feletti are acquiring resistance to the most important drugs, the quinoline antimalarials and artemisinin derivatives. Also, many ecosystems favor the ready reproduction and propagation of malaria vectors: mosquitos of the genus Anopheles Meigen.

In tropical regions where malaria is endemic, alternative therapies based on traditionally used antimalarial plants are used (Milliken, 1997a; Willcox et al. 2004; Blair \& Madrigal, 2005). New drugs introduced into the therapeutic arsenal are mostly derived from natural products (Newman \& Cragg, 2012). Plants provide secondary metabolites that are useful for the treatment of protozoan diseases such as malaria (Pohlit et al., 2013), leishmaniasis, and African and American trypanosomiasis (Schmidt et al., 2012a; 2012b). In fact, traditionally-used antimalarial plants are the origin of the alkaloid quinine (isolated from species of Cinchona) and the sesquiterpene artemisinin (isolated from Artemisia annua L.) that gave rise last century to the synthetic quinoline antimalarials (chloroquine, etc.) and semi-synthetic artemisinin derivatives (sodium artesunate, etc.). These two classes are the basis of artemisinin-combined therapies (ACTs) now used worldwide. Plants also help combat malaria by providing mosquito repellent and insecticidal oils (citronella, neem, etc.), solvent extracts and isolated chemicals (chrysanthamic acid, nicotine, etc.) that have given rise to the pyrethroid, neonicotinoid and other insecticides and repellents (Pohlit et al., 2011a; 2011b).

The Araceae is one of the most botanically diverse families within the monocotolydons. It is comprised of ca.105 genera and 3,300 species worldwide (Croat, 1983; Mayo et al., 1997; Croat, 1998; Ribeiro et al., 1999; Coelho, 2000; Vargas, 2002). The greatest diversity of its species is in tropical America (Croat, 1998). Brazil is among the countries having the largest variety of Araceae, numbering 30 genera and 700 species (Mayo et al.,1997).

Over 800 species of Araceae are of economic importance (ornamental, edible, medicinal). For example, about $10 \%$ of the world population consumes taro corms (rhizomes of Colocasia esculenta (L.) Schott), the most cultivated species of Araceae. It is a foodstuff and foodstock for animals (Pedralli, 2002). Most species of Araceae are ornamental plants the most important of which are from the genera Anthurium Schott, Philodendron Schott, Dieffenbachia Schott, Monstera Adams and Zantedeschia Spreng. (Pedralli, 2002). In the Amazon region, many species of Araceae are used for medicinal purposes, including the treatment of malaria and associated fevers and the most important species are from the genus Philodendron Schott (Milliken et al. 1997a, 1997b; Kvist et al., 2006; López et al., 2006). Species of Araceae traditionally used for malaria, fevers, headaches and liver disorders are reviewed. Relevant literature that reveals the antimalarial potential of extracts and isolated compounds, including median inhibitory concentrations $\left(\mathrm{IC}_{50}\right)$ against Plasmodium falciparum, are also reviewed.

\section{SURVEY METHODS}

This survey was performed mainly on the specialized literature published from July, 2010 until January, 2014, the first record on this topic was in 1977. Searches were performed in the Scifinder Scholar, Scielo, PubMed, Science Direct databases. In general, searches were performed using the terms Araceae antimalarial plants, Araceae fever, Araceae malaria and Araceae medicinal plants and library book collections and documents were used at the following institutions: HUAZ Herbarium of the University of Amazonia (Colombia) and the National Institute for Amazon Research (Manaus, Brazil). The data were compiled and organized in an Excel (Microsoft) spreadsheet containing information on

Rev. Bras. PI. Med., Campinas, v.17, n.4, p.657-666, 2015. 
species name, regions where the plant is used, preparation methods, parts of the plants used and where available, information on chemical composition and pharmacological properties.

\section{Species of araceae used in the treatment of malaria}

Forty-three bibliographic sources were found on plants used to treat malaria and symptoms of malaria in the Araceae family. These works describe 38 species in 22 genera (Table 1). Philodendron Schott was the most cited genus with seven uses registered by communities in South American countries, including Brazil, Colombia, Equador, Peru and French Guyana (Figure 1). Antimalarial plants of the Araceae family are also found in Central America, Africa, Western Europe, Asia and Southeast Asia.

Twenty-one species of Araceae are specifically used to treat malaria and many are from South America. Thus, the aerial part of folha cheirosa, yeuri cumare (Anthurium oxycarpum Poepp.) is used by the Tacana Amerindians of Bolivia (Deharo et al., 2001) and macerates and decoctions of cipo de tara or tracua (Philodendron cf. linnaei Kunth) are indicated by the Tirios Amerindians of Suriname (Lopéz et al., 2006). Also, taioba (Xanthosoma sagittifolium (L.) Schott) is a widely cultivated tuber that is a foodstuff and foodstock for animals (Aiyeloja \& Bello, 2006) and is used as an antimalarial along the Manso River in Minas Gerais, Brazil (Reskalla, 2001). In northern Brazil, an antimalarial aerial root infusion of a species of Philodendron is prepared by the native Watorik Yanomami (Milliken 1997a). In Togo, Africa, whole plant decoctions of tonflo (Pistia stratiotes L.) are used as antimalarials (Kyei et al., 2012).

\section{Araceae species for fevers, headaches and other symptoms of malaria}

Several plants have uses both in the treatment of malaria and also in the the treatment of the symptoms of malaria. Thus, whole plant decoctions of $P$. stratiotes are used in Togo to treat fevers and malaria infections (Lahitte et al., 1998; Kyei et al., 2012).

Some species of Araceae are not used specifically to treat malaria, but are used to treat symptoms often associated with malaria such as fevers and headaches. So, the indigenous Wayãpi in French Guyana treat fevers with a decoction of Tapi'Ykũ (Philodendron linnaei Kunth) (Grenand et al., 1987). Similarly, the Tukano of southeast Colombia treat headaches by placing fresh inflorescences of madona lily (Spathiphyllum floribundum (Linden \& André) N.E. Br.) on the sick person's forehead (Croat, 1994). Culcasia lancifolia
N.E. Br. has been used by traditional healers to treat headaches, fevers and vomiting (Lekana-Douki et al., 2011).

\section{Traditional methods of preparation of remedies}

Decoction was the method of preparation most cited for antimalarial remedies based on species of Araceae. Leaves and the tubercules were the parts most often cited. Few details on the method of preparation are included in many reports (Table 1). Some methods of preparation and treatments are, however, especially interesting. Three slices of hoa pouk, also called habarala (Alocasia macrorrhizos (L.) G. Don) are boiled with 3 pieces of sugar cane and 7 unpolished rice grains in the Province of Khammouane, Laos. A non-malarious person who drinks the decoction is said to become itchy wheras someone with malaria is said to feel good and is then expected to continue treatment with the decoction (Shirayama et al., 2006). On the Pacific Coast of Colombia, the leaves of mano, also known as guaco de mata or tres dedos (Anthurium cf. tridigitatum Engl.) are macerated and rubbed on the body as a rheumatic treatment for malaria (Blair \& Madrigal, 2005). Similarly, the Achuar Jívaro of Peru apply hot leaves of a species of Monstera on the skin to relieve liver pain (Lewis et al.,1977; cited in Croat, 1994).

Therapeutic preparations often involve species from Araceae and other families. Corazón de Jesús or Jesus's heart (Caladium bicolor Vent.) leaves are boiled in $1 \mathrm{~L}$ of water until half the volume evaporates and then lemon (Citrus $\times$ limon (L.) Osbeck) is added. The resulting liquid is allowed to sit to catch the morning dew and consumed on an empty stomach for 9 consecutive mornings in the treatment of inflamed liver (Blair \& Madrigal, 2005).

\section{Distribution of araceae species used in the treatment of malaria and related symptoms \\ Species of Araceae are used for the} treatment of malaria and its symptoms throughout the tropical regions of the world (Figure 1). Poverty and lack of access to health services in many countries make these plants an important alternative for the treatment of malaria. Reports from the African nations of Ivory Coast, Kenya, Benin, Gabon and Togo have revealed eight antimalarial species belonging to the genera Amorphophallus Blume ex Decne, Anchomanes Schott, Culcasia P. Beauv., Homalomena Schott, Pistia L. and Pothos L. In the Amazon region, the largest numbers of Araceae species are used as antimalarials. The neotropical genera Philodendron Schott and Anthurium Schott are used by these Amerindian ethnic groups: Yanomami (Brazil), Tirios (Suriname), Wayãpi (French Guyana), Makuna and Miraña (Colombia) 
TABLE 1. Species of the Araceae family used in the treatment of malaria and malaria symptoms.

\begin{tabular}{llll}
\hline Species & Local name & $\begin{array}{l}\text { People, Region } \\
\text { where used }\end{array} \quad$ Use Pource used $\quad$ Preparation & Part un \\
\hline
\end{tabular}

Alocasia

macrorrhizos (L.) G.

Don (APGIII 2009)

[Name cited:

Alocasia macrorrhiza

(L.) Schott]
Sri Lanka;

Bourapar District

Khammouane

Province LAO
Boil 3 slices

with 3 parts

sugar cane

and 7 whole

grains of rice,

drink.
Edirisinghe,1999

Shirayama et al.

2006

\begin{tabular}{lllll}
$\begin{array}{l}\text { Amorphophallus } \\
\text { bequaertii De Wilde }\end{array}$ & $\begin{array}{l}\text { Mbandakabiri, } \\
\text { Ikomalyakabiri }\end{array}$ & Africa & Malaria, fever & Tuber \\
\hline $\begin{array}{l}\text { Anchomanes } \\
\text { difformis(Blume) }\end{array}$ & forest anchomanes & $\begin{array}{l}\text { Benin, Côte } \\
\text { d'lvoire }\end{array}$ & $\begin{array}{l}\text { Malaria, } \\
\text { analgesic }\end{array}$ & $\begin{array}{l}\text { Leaves, } \\
\text { Rhizomes/ } \\
\text { Roots }\end{array}$ \\
& & & & Rots
\end{tabular}

Place fresh tuber in hot water, filter, use filtrate for rectal injection
Tshibangu et al., 2002

Adjano cited in Bero et al. 2009; Almeida et al., 2001; Atindehou et al. 2004

Ingano Macoa

Amerindians,

Mocoa, Putumayo, Fever sores Sap Colombia

Caustic sap

is applied

directly on

fever sores

Schultes \&

Raffauf, 1990
Anthurium sp.
Secoya

Amerindians,

Anthurium uleanum

Engl. $\begin{array}{ll}\text { Amerindians, Headaches } & \text { Roots } \\ \text { Amazonia } & \end{array}$

Schultes \&

Raffauf, 1990

(based on

Vickers 220);

Croat, 1994

\begin{tabular}{|c|c|c|c|c|c|c|}
\hline $\begin{array}{l}\text { Anthurium } \\
\text { oxycarpum Poeppig }\end{array}$ & $\begin{array}{l}\text { folha cheirosa; yeuri } \\
\text { cumare }\end{array}$ & $\begin{array}{l}\text { Indigenous } \\
\text { Tacana, Bolivia }\end{array}$ & Malaria & Aerial parts & - & $\begin{array}{l}\text { Deharo et al., } \\
2001\end{array}$ \\
\hline $\begin{array}{l}\text { Anthurium cf. } \\
\text { tridigitatum }\end{array}$ & $\begin{array}{l}\text { Mano, guaco de } \\
\text { mata, tres dedos, } \\
\text { corrientoso, } \\
\text { deshinchador }\end{array}$ & $\begin{array}{l}\text { Costa pacífica, } \\
\text { Colombia }\end{array}$ & $\begin{array}{l}\text { Rheumatic } \\
\text { pain caused } \\
\text { by malaria }\end{array}$ & Leaves & $\begin{array}{l}\text { Macerated } \\
\text { leaves rubbed } \\
\text { over whole } \\
\text { body }\end{array}$ & $\begin{array}{l}\text { Blair \& Madrigal, } \\
2005\end{array}$ \\
\hline $\begin{array}{l}\text { Arisaema triphyllum } \\
\text { (L.) Schott }\end{array}$ & - & $\begin{array}{l}\text { Menomini and } \\
\text { Iroquois tribes }\end{array}$ & Headaches & - & - & Croat, 1994 \\
\hline Arum maculatum L. & Wild arum & Europe & Malaria & - & - & $\begin{array}{l}\text { Zwinger, 1696, } \\
\text { cited by Adams, } \\
2011\end{array}$ \\
\hline $\begin{array}{l}\text { Caladium bicolor } \\
\text { Vent. }\end{array}$ & $\begin{array}{l}\text { Pana, corazón de } \\
\text { Jesús }\end{array}$ & $\begin{array}{l}\text { Costa pacífica, } \\
\text { Colombia }\end{array}$ & $\begin{array}{l}\text { Swollen liver, } \\
\text { liver tonic }\end{array}$ & Leaves & $\begin{array}{l}\text { Boil } 5-6 \text { leaves } \\
\text { in } 1 \mathrm{~L} \text { of water } \\
\text { until } 1 / 2 \text { volume } \\
\text { evaporated. } \\
\text { Add lemon, } \\
\text { allow to sit } \\
\text { in morning } \\
\text { dew. Drink } \\
9 \text { mornings } \\
\text { before eating }\end{array}$ & $\begin{array}{l}\text { Blair \& Madrigal, } \\
2005\end{array}$ \\
\hline $\begin{array}{l}\text { Colocasia affinis } \\
\text { Schott }\end{array}$ & & $\begin{array}{l}\text { Eastern Himalayan } \\
\text { India }\end{array}$ & Febrifuge & Leaves & & Prakash, 2005 \\
\hline $\begin{array}{l}\text { Colocasia esculenta } \\
\text { (L.) Schott }\end{array}$ & Taro (saru) & Brazil & Malaria & & - & $\begin{array}{l}\text { Pravakar- } \\
\text { Padhial, } 2011\end{array}$ \\
\hline
\end{tabular}

continua... 
TABLE 1. Species of the Araceae family used in the treatment of malaria and malaria symptoms.

continuação...

\begin{tabular}{|c|c|c|c|c|c|c|}
\hline $\begin{array}{l}\text { Culcasia lancifolia } \\
\text { N.E. Br. }\end{array}$ & - & Kele, Gabon & Fever & & - & $\begin{array}{l}\text { Lekana-Douki, } \\
\text { et al., } 2011\end{array}$ \\
\hline $\begin{array}{l}\text { Cyrtosperma } \\
\text { johnstonii N.E. Br. }\end{array}$ & - & India & Headaches & $\begin{array}{l}\text { Leaves, } \\
\text { flowers, roots/ } \\
\text { rhizome or } \\
\text { whole plant }\end{array}$ & - & Gosling, 2001 \\
\hline Dieffenbachia sp. & Patiquina & Loreto, Perú & Malaria & Leaves & - & Kvist et al., 2006 \\
\hline $\begin{array}{l}\text { Homalomena } \\
\text { propingna } \\
\text { [presumably } \\
\text { Homalomena } \\
\text { propinqua Schott] }\end{array}$ & Nyato & $\begin{array}{l}\text { Muruts, Sabah, } \\
\text { Malaysia }\end{array}$ & Chills & - & $\begin{array}{l}\text { Heated, } \\
\text { placed on } \\
\text { forehead }\end{array}$ & Kulip, 2003 \\
\hline $\begin{array}{l}\text { Homalomena rubra } \\
\text { Hassk. }\end{array}$ & Lung bala & Kenya & $\begin{array}{l}\text { Splenomegaly, } \\
\text { malaria, } \\
\text { rubefacient }\end{array}$ & Roots & Decoction & $\begin{array}{l}\text { Leaman et al., } \\
1995\end{array}$ \\
\hline $\begin{array}{l}\text { Lasia spinosa (L.) } \\
\text { Thwaites }\end{array}$ & - & Vietnam & Malaria & Whole plant & - & Tran et al., 2003 \\
\hline Monstera sp. & - & $\begin{array}{l}\text { Achuar Jívaro, } \\
\text { Peru }\end{array}$ & Liver pain & Leaves & $\begin{array}{l}\text { Hot leaves } \\
\text { applied to skin } \\
\text { over the liver } \\
\text { to alleviate } \\
\text { pain }\end{array}$ & $\begin{array}{l}\text { Lewis et } \\
\text { al.,1977. cited } \\
\text { by Croat, } 1994\end{array}$ \\
\hline $\begin{array}{l}\text { Monstera deliciosa } \\
\text { Liebm. }\end{array}$ & - & Brazil & Malaria & - & - & $\begin{array}{l}\text { Brandão et al., } \\
1985\end{array}$ \\
\hline $\begin{array}{l}\text { Monstera spruceana } \\
\text { (Schott) Engl. }\end{array}$ & - & $\begin{array}{l}\text { Achuar Jívaro, } \\
\text { Peru }\end{array}$ & Liver & Leaves & $\begin{array}{l}\text { Hot leaves } \\
\text { applied to skin } \\
\text { over the liver } \\
\text { to alleviate } \\
\text { pain }\end{array}$ & $\begin{array}{l}\text { Lewis et al., } \\
1977 \text { cited by } \\
\text { Croat, } 1994\end{array}$ \\
\hline Philodendron sp. & - & $\begin{array}{l}\text { Indigenous Watorik } \\
\text { Yanomami, Brazil }\end{array}$ & Malaria & Roots & $\begin{array}{l}\text { Infusion of } \\
\text { aromatic, } \\
\text { aerial roots, } \\
\text { oral }\end{array}$ & Milliken, 1997a \\
\hline Philodendron sp. & & Quichua, Ecuador & Hepatitis & & & $\begin{array}{l}\text { Marles et } \\
\text { al.,1988 }\end{array}$ \\
\hline $\begin{array}{l}\text { Philodendron cf. } \\
\text { deflexum Poepp. ex } \\
\text { Schott }\end{array}$ & $\begin{array}{l}\text { Taracua; bejuco } \\
\text { agraz, meonomisi } \\
\text { (Makuna), } \\
\text { pijimacu (Yukuna); } \\
\text { huncageme } \\
\text { (Huaorani), u'cu } \\
\text { (Secoya), ya'i } \\
\text { (Siona); chuhudaek, } \\
\text { itininga, pantorrilla }\end{array}$ & $\begin{array}{l}\text { Brazil, Colombia } \\
\text { (Indigenous } \\
\text { Makuna), Ecuador, } \\
\text { Peru }\end{array}$ & Fever & Roots & $\begin{array}{l}\text { Softer pendant } \\
\text { vines are } \\
\text { macerated } \\
\text { and drunk in } \\
\text { cold water for } \\
\text { fever }\end{array}$ & $\begin{array}{l}\text { López et al. } \\
2006\end{array}$ \\
\hline $\begin{array}{l}\text { Philodendron } \\
\text { fragantissimum } \\
\text { (Hook.) Kunth }\end{array}$ & - & Tropical Americas & $\begin{array}{l}\text { Liver pain } \\
\text { relief }\end{array}$ & Leaves & $\begin{array}{l}\text { Cold poultice } \\
\text { of the plant } \\
\text { placed over } \\
\text { the liver, for } \\
\text { pain. Leaves } \\
\text { may also be } \\
\text { heated }\end{array}$ & $\begin{array}{l}\text { Lewis et al., } \\
\text { 1977, cited by } \\
\text { Croat, } 1994\end{array}$ \\
\hline
\end{tabular}

continua...

Rev. Bras. PI. Med., Campinas, v.17, n.4, p.657-666, 2015. 
TABLE 1. Species of the Araceae family used in the treatment of malaria and malaria symptoms.

continuação...

\begin{tabular}{|c|c|c|c|c|c|c|}
\hline Philodendron cf. & $\begin{array}{l}\text { Cipo de tara, tracua; } \\
\text { bejuco quemador; } \\
\text { orejita de venado, } \\
\text { ellapapar }\end{array}$ & $\begin{array}{l}\text { Brazil, Colombia, } \\
\text { Peru, Suriname } \\
\text { (indigenous Tirios) }\end{array}$ & Malaria & Whole plant & $\begin{array}{l}\text { Decoction of } \\
\text { macerated } \\
\text { plant for } \\
\text { washings }\end{array}$ & $\begin{array}{l}\text { López et al., } \\
2006\end{array}$ \\
\hline & Tapi`Ykũ & $\begin{array}{l}\text { Wayapi, French } \\
\text { Guiana }\end{array}$ & $\begin{array}{l}\text { Fever } \\
\text { associated } \\
\text { with tabu }\end{array}$ & Leaves & $\begin{array}{l}\text { Decoction } \\
\text { for external } \\
\text { washings }\end{array}$ & $\begin{array}{l}\text { Grenand et al., } \\
1987\end{array}$ \\
\hline $\begin{array}{l}\text { Philodendron cf. } \\
\text { uleanum Engl. }\end{array}$ & - & Miraña, Colombia & Malaria, fever & - & Infusion & $\begin{array}{l}\text { Schultes \& } \\
\text { Raffauf, } 1994\end{array}$ \\
\hline $\begin{array}{l}\text { Pinellia ternata } \\
\text { (Thunb.) Ten. ex } \\
\text { Breitenb. }\end{array}$ & - & - & Intense fever & Rhizome & $\begin{array}{l}\text { In mixture } \\
\text { with Artemisia } \\
\text { annua }\end{array}$ & $\begin{array}{l}\text { Willcox et al., } \\
2004\end{array}$ \\
\hline Pistia stratiotes L. & Tonflo & $\begin{array}{l}\text { Maritime Region, } \\
\text { Togo }\end{array}$ & Malaria & Whole plant & $\begin{array}{l}\text { Decoction, } \\
\text { taken orally }\end{array}$ & $\begin{array}{l}\text { Koudouvo et al., } \\
2011\end{array}$ \\
\hline $\begin{array}{l}\text { Pothos ovatifolius } \\
\text { Engl. }\end{array}$ & Aka malung & Kenya & $\begin{array}{l}\text { Splenomegaly, } \\
\text { malaria }\end{array}$ & Leaves & Poultice & $\begin{array}{l}\text { Leaman et al., } \\
1995\end{array}$ \\
\hline $\begin{array}{l}\text { Rhaphidophora } \\
\text { decursiva (Roxb.) } \\
\text { Schott }\end{array}$ & - Guaimbê-sulcado & Brazil & Malaria & - & - & $\begin{array}{l}\text { Zhang et al., } \\
2001\end{array}$ \\
\hline $\begin{array}{l}\text { Rhaphidophora } \\
\text { pertusa (Roxb.) } \\
\text { Schott }\end{array}$ & & $\begin{array}{l}\text { Manokwari, (West } \\
\text { Papua Province), } \\
\text { Merdey, Wasior, } \\
\text { Indonesia }\end{array}$ & Liver diseases & Leaves & - & Lense, 2011 \\
\hline $\begin{array}{l}\text { Scindapsus } \\
\text { officinalis (Roxb.) } \\
\text { Schott }\end{array}$ & Takbir gach & Bangladesh & Fever, pain & Leaves & $\begin{array}{l}\text { Powdered } \\
\text { leaves are } \\
\text { drunk for } 21 \\
\text { days }\end{array}$ & $\begin{array}{l}\text { Rahmatullah et } \\
\text { al., } 2009\end{array}$ \\
\hline $\begin{array}{l}\text { Spathiphyllum } \\
\text { floribundum (Linden } \\
\text { \& André) N.E. Br. }\end{array}$ & Madonna Lily & $\begin{array}{l}\text { Indigenous Tukano } \\
\text { and Gwanano } \\
\text { (near the Papurf } \\
\text { River), Southeast } \\
\text { Colombia }\end{array}$ & Headaches & $\begin{array}{l}\text { Fresh } \\
\text { inflorescences }\end{array}$ & $\begin{array}{l}\text { Placed directly } \\
\text { on forehead }\end{array}$ & Croat, 1994 \\
\hline $\begin{array}{l}\text { Symplocarpus } \\
\text { foetidus (L.) W. } \\
\text { Salisb. }\end{array}$ & - & Micmac Indians & Headaches & Leaves & $\begin{array}{l}\text { Inhalation of } \\
\text { volatile oils } \\
\text { from ground } \\
\text { leaves }\end{array}$ & $\begin{array}{l}\text { Lewis \& Elvin } \\
\text { 1977, cited by } \\
\text { Croat, } 1994\end{array}$ \\
\hline $\begin{array}{l}\text { Xanthosoma } \\
\text { atrovirens K. Koch \& } \\
\text { C.D. Bouché }\end{array}$ & - & - & $\begin{array}{l}\text { For swollen } \\
\text { liver after } \\
\text { bouts of } \\
\text { swamp or } \\
\text { malaria fever }\end{array}$ & Leaves & $\begin{array}{l}\text { Fresh leaves } \\
\text { applied to } \\
\text { body }\end{array}$ & $\begin{array}{l}\text { Peckolt, } 1893 \\
\text { and Uphof, } \\
\text { 1959, cited by } \\
\text { Croat, } 1994 .\end{array}$ \\
\hline $\begin{array}{l}\text { Xanthosoma } \\
\text { sagittifolium (L.) } \\
\text { Schott }\end{array}$ & Taioba, taiá & $\begin{array}{l}\text { Rio Manso-MG, } \\
\text { Brazil }\end{array}$ & Malaria & - & - & $\begin{array}{l}\text { Reskalla, 2001, } \\
\text { cited by Pedralli, } \\
2002\end{array}$ \\
\hline $\begin{array}{l}\text { Xanthosoma undipes } \\
\text { (K. Koch \& C.D. } \\
\text { Bouché) K. Koch }\end{array}$ & Tall elephant's ear & Costa Rica & Malaria & - & - & $\begin{array}{l}\text { Chinchilla- } \\
\text { Carmona et al., } \\
2011\end{array}$ \\
\hline
\end{tabular}


and Secoya and Tacana, and by African descendants (Pacific Coast, Colombia). Interestingly, no genus of antimalarial Araceae was reportedly used on both the African and American Continents thus providing evidence for the local distribution of the species used.

\section{Antiplasmodial activity and toxicity of species of araceae}

Extracts of plants of the Araceae exhibit antimalarial potential and also cytotoxicity. The hexane and ethanol extracts of the stems of the aquatic plant aninga (Montrichardia linifera (Arruda) Schott) were inactive in vitro against $P$. falciparum Dd2 strain. However, the dichloromethane fraction of the ethanol extract exhibited high antiplasmodial activity $\left(\mathrm{IC}_{50}<10 \mu \mathrm{g} / \mathrm{mL}\right)$ and toxicity to the brine shrimp species Artemia salina (Amarante et al., 2011). M. linifera from Belém, Brazil exhibited leaf ethanol extracts with no toxicity to $A$. salina $\left(D_{50}>\right.$ $500 \mu \mathrm{g} / \mathrm{mL}$ ) and moderate inhibition of $P$. falciparum W2 strain $\left(\mathrm{IC}_{50}=11.7 \mu \mathrm{g} / \mathrm{mL}\right)$ (Costa et al., 2009). In other work, dichloromethane root extracts of Culcasia lancifolia inhibited the growth of FCB and W2 strains of $P$. falciparum $\left(\mathrm{IC}_{50}=8.9\right.$ and
$10.0 \mu \mathrm{g} / \mathrm{mL}$, respectively) and exhibited toxicity to MRC-5 cells. The root methanol extract exhibited moderate antiplasmodial activity $\left(\mathrm{IC}_{50}=25.0\right.$ and $16.0 \mu \mathrm{g} / \mathrm{mL}$ against FCB and W2 strains of $P$. falciparum, respectively) (Lekana-Douki et al., 2011). Root extracts of forest anchomanes (Anchomanes difformis (Blume) Engl.) failed to inhibit ( $\mathrm{IC}_{50}>100$ $\mu \mathrm{g} / \mathrm{mL}$ ) the 3D7 strain of $P$. falciparum and were cytotoxic (Bero et al. 2009).

Water and ethanol extracts of the leaves of water lettuce (Pistia stratiotes L.) were apparently well-tolerated and exhibited antiarthritic and antipyretic effects in formalin-induced arthritis and LPS-induced fever in Sprague-Dawley rats (Kyei et al., 2012). On the other hand, the sap of Caladium bicolor is toxic and can even produce asphyxia (Flores et al. 2001). Isolation of the antiplasmodial and cytotoxic components from the extracts of plants of the Araceae is necessary for a better understanding of the medicinal potential of this family.

\section{Chemistry of antimalarial species of araceae}

Oxalic acid is frequently deposited as

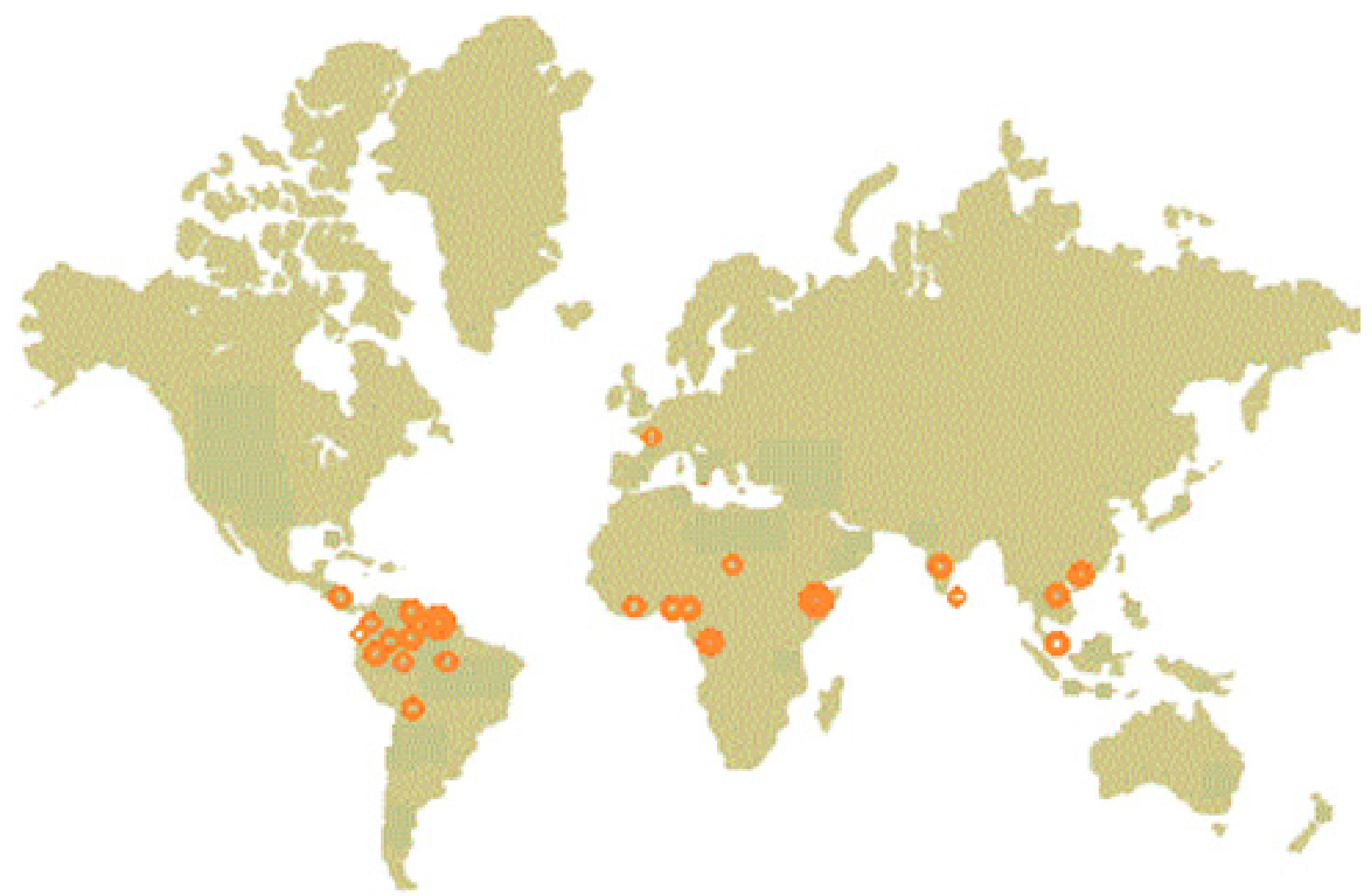

FIGURE 1. World locations where species of Araceae are used to treat malaria and its symptoms. Note: An orange colored point indicates where an Araceae species has been reported as being used to treat malaria or its symptoms. This mapa was generated based on the countries represented in Table 1. 
crystals of calcium oxalate (Figure 2) in plants of the Araceae and is responsible for the toxicity of some genera (e.g. Dieffenbachia Schott). A large variety of anthocyanines have been identified in the flowers, fruit, leaves and leaf stems of 59 species of Araceae (Williams et al., 1981). The most commonly occurring pigment in these species was cyanidin 3-O-rutinoside, however, pelargonidin 3-rutinoside is also regularly found in the Araceae.

Leaves and branches of guaimbê-sulcado (Rhaphidophora decursiva (Roxb.) Schott) were extracted with methanol. The dry extract was defatted with hexanes. The chloroform soluble fraction of this extract was evaporated and chromatographed on silica gel using an acetone-chloroform gradient. Further normal phase, flash or reverse-phase chromatographies on the resulting fractions provided 14 compounds. Six of these compounds exhibited in vitro antiplasmodial activity (Zhang et al., 2001). The most active against $P$. falciparum D6 and W2 strains were the neolignan threo-polysyphorin $\left(\mathrm{IC}_{50}=\right.$ 404 and $368 \mathrm{ng} / \mathrm{mL}$, respectively; Figure 2) and the benzoperoxide rhaphidecurperoxin $\left(\mathrm{IC}_{50}=540\right.$ and $420 \mathrm{ng} / \mathrm{mL}$, respectively; Figure 2). The neolignans rhaphidecursinol $A$ and $B$ and lignans grandisin and epigrandisin were less active. To our knowledge, the above is the only report on antimalarial components from the Araceae.

\section{FINAL REMARKS}

A number of South American Araceae species are traditionally used in the treatment of malaria and its symptoms. Despite the in vitro inhibitory activity of extracts, fractions and isolated constituents against the human malaria parasite Plasmodium falciparum we found no in vivo antimalarial study in animal models for this family. Studies on the in vitro and in vivo antimalarial activity are needed to further explore the antimalarial potential of the Araceae.

\section{ACKNOWLEDGEMENTS}

The authors thank the Herbarium at the Universidade de La Amazonia in Colombia for the use of bibliographic materials. Funding was provided by grants from the Brazilian National Council for Scientific and Technological Development (CNPQ, National Malaria Network and Bionorth Program), the Amazonas State Research Support Foundation (FAPEAM, PRONEX). G. F., R. B. S. L. and A. M. P. would like to recognize the following scholarships received from CNPq: DTI, GD (383557/2010$0),(554317 / 2010-9)$ and $P Q$ (311.649/2011-4), respectively.

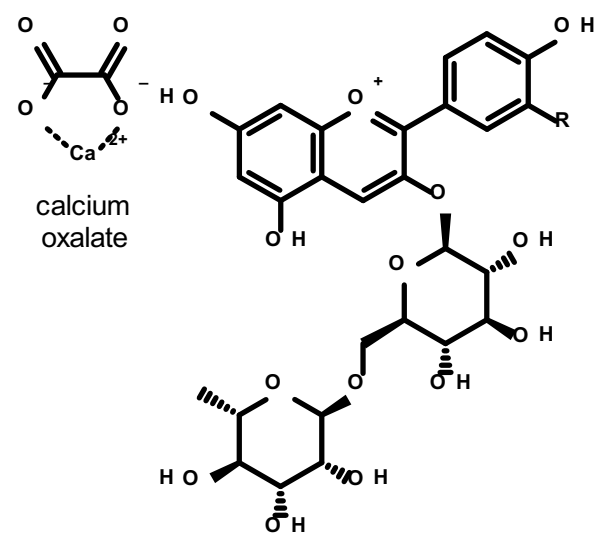

$\mathrm{R}=\mathrm{OH}$ cyanidin 3-O-rutinoside $\mathrm{R}=\mathrm{H}$ pelargondin 3-O-rutinoside

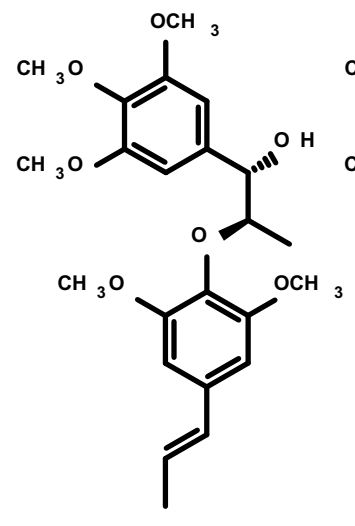

threo-polysyphorin

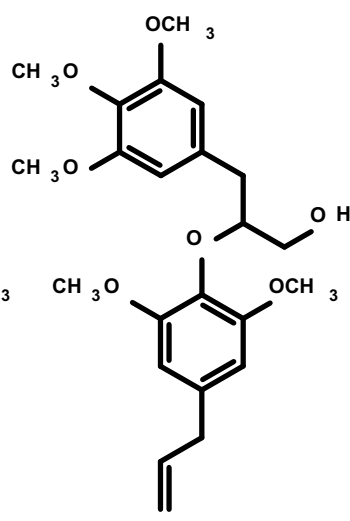

rhaphidecursinol $\mathrm{A}$

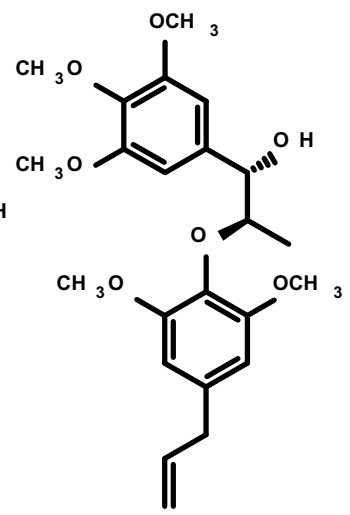

threo-rhaphidecursinol B<smiles>COc1cc(O)cc(/C=C/CCCCCC(C)OC)c1C(=O)O</smiles><smiles>COc1cccc(OC)c1OC</smiles><smiles>COc1cc([C@@H]2O[C@H](C)[C@@H](C)[C@H]2C)cc(OC)c1OC</smiles>
grandisin<smiles>COc1cc(C2O[C@H](c3cc(OC)c(OC)c(OC)c3)[C@@H](C)[C@H]2C)cc(OC)c1OC</smiles>

rhaphidecurperoxin

FIGURE 2. Antiplasmodial chemical constituents of Rhaphidophora decursiva. 


\section{REFERENCES}

ADAMS, M. et al. Malaria in the renaissance: Remedies from European herbals from the $16^{\text {th }}$ and 17 th century. Journal of Ethnopharmacology, v.133 (2), p. 278288, 2011.

ADEBAYO, J.O.; KRETTLI, A.U. Potential antimalarials from Nigerian plants: a review. Journal of Ethnopharmacology, v.133, n.2, p. 289-302, 2011.

AIYELOJAA. A; BELLO O.A. Ethnobotanical potentials of common herbs in Nigeria: a case study of Enugustate. Educational Research and Review, v.1, n.1, p.16-22, 2006.

ALMEIDA, R.N. et al. Plants with central analgesic activity. Phytomedicine, v.8, n.4, p.310-322, 2001.

AMARANTE et al. Estudo fitoquímico biomonitorado pelos ensaios de toxicidade frente à Artemia salina e de atividade antiplasmódica do caule de aninga (Montrichardia linifera). Acta Amazonica, v.41, n.3, p.431-43, 2011.

ATINDEHOU, K et al. Antitrypanosomal and antiplasmodial activity of medicinal plants from $\mathrm{C}^{\wedge}$ ote d'Ivoire. Journal of Ethnopharmacology, v.90, p. 221-227. 2004.

BERO, J. et al. In vitro antiplasmodial activity of plants used in Benin in traditional medicine to treat malaria. Journal of Ethnopharmacology, v.122, n.3, 21, p.439 - 444, 2009.

BLAIR, S.; MADRIGAL, B. Plantas antimaláricas de Tumaco: Costa Pacífica colombiana. 1 ed., Medellin: University of Antioquia, 2005. 347p.

BRANDÃO, M. et al. Antimalarial experimental chemotherapyusing natural products. Ciência e Cultura, v.37, p.1152-1163,1985.

CHINCHILLA-CARMONA, M. et al. Evaluación in vivo de la actividad antimalarica de 25 plantas provenientes de una reserva de conservación biológica de Costa Rica. Revista Chilena de Historia Natural, v.84, p.115-123, 2011.

COELHO, N. M. A. Philodendron Schott (Araceae): Morfología e taxonomía das especies da Reserva da Macae da Cima - Nova Friburgo, Rio de Janeiro, Brasil. Rodriguesia, v. 51, n.78/79, p.21-68, 2000.

COSTA, E.S.S. et al. Estudos farmacognósticos, fitoquímicos, atividade antiplasmódica e toxicidade em Artemia salina de extrato etanólico de folhas de Montrichardia linifera (Arruda) Schott, Araceae. Revista Brasileira de Farmacognosia, v.19, n.4, p.834-838, 2009.

CROAT, T. B. A revision of the genus Anthurium (Araceae) of Mexico and Central America. Part. I: Mexico and middle America. Annals of Missouri Botanical Garden, v.70, n.2, p.211-416, 1983.

CROAT, T.B. The use of the new world Araceae as drug plants. Journal of Japanese Botany, v.69, n.4, p.185203, 1994.

CROAT, T.B. History and current status of systematic research with Araceae. Aroideana, v.21, p. 26$145,1998$.

DEHARO, E. et al. A search for natural bioactive compounds in Bolivia through a multidisciplinary approach. Part V. Evaluation of the antimalarial activity of plants used by the Tacana Indians. Journal of Ethnopharmacology, v.77, p.91-98, 2001.
EDIRISINGHE, S. Plant Based Antimalarials of the Indigenous Herbal Traditions of Sri Lanka. Sri Lanka: National Science Foundation, 1999. 23p.

FLORES, J.S. et al. Plantas de la flora yucatanense que provocan alguna toxicidad en el humano. Revista Biomédica, v.12, p.86-96, 2001.

GOSLING, D. Religion and ecology in India and Southeast Asia. London: Routledge, 2001. 215p.

GRENAND, P. et al. Pharmacopées traditionnelles en Guyane: Créoles, Wayãpi, Palikur. Paris: Orstom,1987. 569p.

KOUDOUVO, K. et al. An ethnobotanical study of antimalarial plants in Togo Maritime Region. Journal of Ethnopharmacology, v.134, p.183-190, 2011.

KULIP, J. An ethnobotanical survey of medicinal and other useful plants of Muruts in Sabah, Malaysia. Telopea, v.10, n.1, p.81-98, 2003.

KVIST, L.P. et al. Identification and evaluation of Peruvian plants used to treat malaria and leishmaniasis. Journal of Ethnopharmacology, v.106, p.390-402, 2006.

KYEI, S. et al. The efficacy of aqueous and ethanolic leaf extracts of Pistia stratiotes Linn. in the management of arthritis and fever. Journal of Medical and Biomedical Sciences, v.1 n.2, p.29-37, 2012.

LAHITTE, H.J. et al. Plantas medicinales Rioplatenses. Buenos Aires: Editorial L.O.L.A., 1998, 240p.

LEAMAN, D. A. et al. Malaria remedies of the Kenyah of the Apo Kayan, East Kalimantan, Indonesian Borneo: a quantitative assessment of local consensus as an indicator of biological efficacy. Journal of Ethnopharmacology, v.49, p.1-16, 1995.

LEKANA-DOUKI, J. B. et al. In vitro antiplasmodial activity and cytotoxicity of nine plants traditionally used in Gabon. Journal of Ethnopharmacology, v.133, p.1103-1108, 2011.

LENSE, O. Biological screening of selected traditional medicinal plants species utilized by local people of Manokwari, West Papua Province. Musantara Biocience, v.3, n.3, p.145-150, 2011.

$L O ́ P E Z$, R. et al. Manual de identificación de especies no maderables del corregimiento de Tarapacá. Bogotá: Instituto Amazónico de Investigaciones Científicas (SINCHI) - GTZ (Germany), 2006. 120p.

MARLES, R.J. et al. A contribution to the ethnopharmacology of the lowland quichua people of amazonian Ecuador. Revista da Academia Colombiana de Ciencias Exactas, Físicas e Naturales, v.16, n.63, p.111120,1988 .

MAYO, S. J. et al. The genera of Araceae. Kew (UK): Royal Botanic Garden, 1997. 370p.

MILLIKEN, W. Traditional antimalarial medicine in Roraima, Brazil. Economic Botany, v.51, n.3, p.212237,1997a.

MILLIKEN, W. Plants for malaria plants for fever: medicinal species in Latin America - a bibliographic survey.Kew (UK): Royal Botanic Garden, 1997b.116p.

MUÑOZ, V. et al. A search for natural bioactive compounds in Bolivia through a multidisciplinary approach Part I. Evaluation of the antimalarial activity of plants used by the Chacobolndians. Journal of Ethnopharmacology, v.69, p.127-137, 2000.

NEWMAN, D.J.; CRAGG, G.M. Natural products as sources of new drugs over the 30 years from 1981 to

Rev. Bras. PI. Med., Campinas, v.17, n.4, p.657-666, 2015. 
2010. Journal of Natural Products, v.75, p.311-335, 2012.

PEDRALLI, G. Dioscoreaceae e Araceae: aspectos taxonômicos, etnobotânicos e espécies nativas com potencial para melhoramento genético. In: SIMPÓSIO NACIONAL SOBRE AS CULTURAS DO INHAME E DO TARO II, 2002, João Pessoa. Resumo, João Pessoa: EMEPA-PB, 2002. v.2, 234 p.

POHLIT, A.M. et al. Patent literature on mosquito repellent inventions which contain plant essential oils-a review. Planta Medica, v.77, p.598-617, 2011a.

POHLIT, A.M. et al. Plant extracts, isolated phytochemicals, and plant-derived agents which are lethal to arthropod vectors of human tropical diseases-A review. Planta Medica, v.77, p.618-630, 2011b.

POHLIT, A.M. et al. Amazonian plant natural products: perspectives for discovery of new antimalarial drug leads. Molecules, v.18, p.9219-9240, 2013.

PRAKASH, K. C. Ethnomedicinal botany of the Apatani in the Eastern Himalayan region of India. Journal of Ethnobiology and Ethnomedicine, v.1, p.1-8, 2005.

PRAVAKAR, P.. Arum Family (Araceae): Taro, in: http:// agriorissa.blogspot.co.uk/2011/10/arum-family-araceaetaro.html. Access on 9/10/2011.

RAHMATULLAH, M. et al. A survey of medicinal plants in two areas of Dinajpur district, Bangladesh including plants which can be used as functional foods. AmericanEurasian Journal of Sustainable Agriculture, v.3, n.4, p.862-876, 2009.

RESKALLA, A. Inhame, saúde como alimento e lucro como produto. Belo Horizonte: Estado de Minas/ Agropecuário, p. 6-7, 2001.

RIBEIRO, J. E. et al. Flora da Reserva Ducke. Guia de identificaçao das plantas vasculares de uma floresta de terra-firme na Amazonía Central. Manaus: INPA/ DFID, 1999. 816p.

SCHMIDT, T.J. et al. The potential of secondary metabolites from plants as drugs or leads against protozoan neglected diseases-part I. Current Medicinal Chemistry, v.19, p.2128-2175, 2012a.

SCHMIDT, T.J. et al. The potential of secondary metabolites from plants as drugs or leads against protozoan neglected diseases-part II. Current Medicinal Chemistry, v.19, p.2176-2228, 2012b.

SCHULTES,R. E.; RAFFAUF,R.F. The healing forest: medicinal and toxic plants of the northwest Amazonia. Portland (USA): Dioscorides Press, 1990. v. $2,484 p$.

SCHULTES, R.E.; RAFFAUF, R.F. De plantis toxicariis e mundo novo tropicale commentationes XXXIX febrifuges of northwest Amazonia. Harvard Pap In Bot 5: 50-68, 1994.

SHIRAYAMA, Y. et al. Modern medicine and indigenous health beliefs: malaria control alongside "sadsanaphee"(animist belief system) in LAO PDR. Southeast Asian Journal of Tropical Medicine and Public Health v.37, p.622-629, 2006.

TRAN, Q. et al. In vitro antiplasmodial activity of antimalarial medicinal plants used in Vietnamese traditional medicine. Journal of Ethnopharmacology, v.86, n.2-3, p.249-252, 2003.

TSABANG, N. et al. Ethnopharmacological survey of Annonaceae medicinal plants used to treat malaria in four areas of Cameroon. Journal of Ethnopharmacology, v.139, p.171-180, 2011.

TSHIBANGU, N.J. et al. Screening of African medicinal plants for antimicrobial and enzyme inhibitory activity. Journal of Ethnopharmacology, v.80, p.25-35, 2002.

VARGAS, W.G. Guía ilustrada de las plantas de las montañas del Quindío y los andes centrales. Manizales (Colombia): Centro Editorial Universidad de Caldas, 2002. 813p.

World Health Organization (WHO). Tratamiento del paludismo grave. Manual practico. 3ed. Geneva (Switzerland): WHO, 2014. 83p.

WILLCOX, M. et al. Traditional herbal medicines for modern times-traditional medicinal plants and malaria. Boca Raton (USA): CRC press, 2004. 508p.

WILLIAMS, C.A. et al. Anthocyanin pigments and leaf flavonoids in the family Araceae. Phytochemistry, v.20, n.2, p.217-234, 1981.

ZHANG, H. et al. Antimalarial compounds from Rhaphidophora decursiva. Journal of Natural Products, v.64, p.772-777, 2001. 